\begin{tabular}{|l|l|l||}
\hline \multicolumn{2}{|c|}{ PublisherInfo } \\
\hline \hline PublisherName & $:$ & BioMed Central \\
\hline \hline PublisherLocation & $:$ & London \\
\hline \hline PublisherImprintName & $:$ & BioMed Central \\
\hline \hline
\end{tabular}

\title{
Natural selection in humans
}

\begin{tabular}{|l|c|l||}
\hline \multicolumn{2}{|c|}{ ArticleInfo } \\
\hline \hline ArticleID & $:$ & 5052 \\
\hline \hline ArticleDOI & $:$ & $10.1186 /$ gb-spotlight-20050118-01 \\
\hline \hline ArticleCitationID & $:$ & spotlight-20050118-01 \\
\hline \hline ArticleSequenceNumber & $:$ & 28 \\
\hline \hline ArticleCategory & $:$ & Research news \\
\hline ArticleFirstPage & $:$ & 1 \\
\hline \hline ArticleLastPage & $:$ & 3 \\
\hline \hline & & RegistrationDate : 2005-1-18 \\
\hline ArticleHistory & $:$ & OnlineDate \\
\hline \hline ArticleCopyright & $:$ & BioMed Central Ltd2005-1-18 \\
\hline \hline ArticleGrants & $:$ & \\
\hline \hline ArticleContext & $:$ & 130596611 \\
\hline \hline
\end{tabular}


For the first time in humans, researchers have discovered a large chromosomal rearrangement that bears the mark of natural selection (Nat Genet 2004, 37:90-95), they report in the February issue of Nature Genetics.

The rearrangement, a 900-kilobase inversion polymorphism, appears in two distinct lineages, $\mathrm{H} 1$ and $\mathrm{H} 2$, that have diverged for as long as 3 million years with no evidence of having recombined. The $\mathrm{H} 2$ lineage - which is rare in Africans, almost nonexistent in East Asians, but found in $20 \%$ of Europeans appears to undergo positive selection in Iceland, with carrier females having $3.2 \%$ more children per generation and higher recombination rates.

"This raises the question of how many such inversions remain to be discovered in the genome and what their effects might be," study co-author Kari Stefansson, chief executive officer of biopharmaceutical company deCODE Genetics in Reykjavik, Iceland, told us. The mechanisms for the increased fertility and recombination rates remain uncertain and point for continued study, he added.

"If you told me beforehand this story without showing me the data, I'd think there was a 10,000 to 1 chance of it being correct, but the data are very, very strong," David Reich of Harvard Medical School, who did not participate in this study, told us. "They carefully attempted to control for environment, for differences between people with few children and many, between north and south, age. It's difficult to imagine this can be an artifact."

The inversion appears at chromosome 17q21.31, a region scrutinized in detail because it contains the gene for microtubule-associated protein tau (MAPT), variants of which are linked with Parkinson disease as well as corticotropin releasing hormone (CRH) receptor 1 (CRHR1). $\mathrm{CRH}$, which is normally released by the mother and embryo soon after the embryo implants in the uterus, appears to protect the embryo from immunologic rejection by the mother. Past studies revealed two main and highly divergent MAPT haplotypes, $\mathrm{H} 1$ and $\mathrm{H} 2$, after which the inversion's two alternative chromosomal orientations are named. The way these lineages dramatically diverged tipped off Stefansson and colleagues to the presence of an inversion, since inversions are known to suppress exchange of variants by recombination in inverted regions. A set of chromosome-specific BAC contigs confirmed the inversion's presence.

The extensive divergence between the lineages suggests their separation predated anatomically modern Homo sapiens and potentially even the genus Homo. Stefansson and colleagues suggest the H2 lineage was introduced into the ancestral human gene pool in Africa from species such as Homo heidelbergensis or Homo erectus.

But Arcadi Navarro of the Universitat Pompeu Fabra in Barcelona, who did not participate in this study, said he wasn't so sure that was the case. "It does seem very unlikely that this polymorphism has been sitting for 3 million years, half the span of time between humanity's split with chimpanzees," he told us. "This estimate for the time of convergence was obtained under the assumption of divergence without the influence of selection. If selection has acted here, as very much seems to be the case, maybe the divergence time is not that long. Maybe selection has been acting within each rearrangement." 
"Given its effect on fertility, you should see the frequency of this variant $\mathrm{H} 2$ double in the population every 400 to 800 years, which would suggest that it would be nearly $100 \%$ in some populations and much rarer in others. What you see, however, is it remaining flat across European populations at roughly 20\%," Reich added. "That's hard to believe."

"The most important direction now is to try and replicate the results. We should try to understand whether this selection is present elsewhere in Europe with people with this haplotype. That will be hard, since you need a big population to test things like fertility," Reich said. Stefansson and colleagues genotyped more than 29,000 Icelanders.

"One question is whether the increase of recombination this inversion produces elsewhere in the genome is due to some recombination-modifying locus. We know a lot about genomics, but little of recombination. This discovery could uncover some regulatory gene that has a dramatic impact on recombination," Navarro told us.

\section{References}

1. Nature Genetetics, [http://www.nature.com/ng]

2. Kari Stefansson, [http://www.decodegenetics.com/main/view.jsp?branch=166819]

3. David Reich, [http://www.hms.harvard.edu/dms/bbs/fac/reichda.html] 